\title{
Difference Analysis between Safety Management System and Airworthiness Management System in Civil Aircraft Design and Manufacture Organization
}

\author{
Sheng Li *, Pei He, Yao Lu, Jing Li \\ China Academy of Civil Aviation Science and Technology, Beijing, 100028, China
}

\begin{abstract}
As a new active safety management method, Safety Management System (SMS) presents a prospective vision of the world's aircraft transport industry on safety management situation. The fundamental purpose of SMS is to make safety management from the current aircraft accident investigation into prior forecast prevention. Based on the systems management and risk management approach, the theoretical Reason Model recommended by International Civil Aviation Organization (ICAO) is used to study the inherent evolutionary relationships between accidents and organizational defects. Meanwhile, through comparative analysis between the regulation requirements, this paper also analyzed the differences between SMS and airworthiness management system, and tentatively explored the implemental suggestion of SMS in civil aircraft design and manufacture organization.
\end{abstract}

Keywords-safety management system (SMS); airworthiness management; reason model; difference analysis; aircraft design and manufacture organization.

\section{INTRODUCTION}

At present, the civil aircraft design and manufacture organization with type certification (TC), production certification (PC) and airworthiness certification (C of A) for its aircrafts are the fundamental and mandatory requirements of Civil Aviation Administration of China(CAAC) to ensure the safety and airworthiness of civil aircraft, and to allow it to enter the aviation market. These requirements are defined and clarified through a series of China Civil Aviation Regulations (CCAR) and airworthiness management system [1]. According to these regulations, civil aircraft design and manufacture organization in China established Design Assurance System(DAS) for aircraft design, Quality System(QS)for aircraft manufacture, fault/defect information report system and unsafe conditions correction and continuous improvement programs (such as service bulletin, etc.) for continuous operation for these aircraft products[2]. Civil aviation airworthiness management department of CAAC operates aircraft airworthiness certification for established DAS, QS and continuous operation system in civil aircraft design and manufacture organization and issues the corresponding documents to complete the management and surveillance for aircraft airworthiness.

In recent years, the International Civil Aviation Organization (ICAO) is promoting a new philosophy of safety management comprehensively, namely the safety management system (SMS). SMS means completely establish and clearly implement of security risk management and security infrastructure operating system [3]. It emphasizes the importance of safety management in a proactive way, and focuses on accident prevention and safety planning, undertake risk information collection, analysis, monitoring and troubleshooting. It essentially transfers single experience management into a systematic and scientific objective management, and eventually improves the safety management, raises the level of safety for enterprises. Now, SMS has become a powerful means for developed countries to effectively improve the overall safety level of complex aerospace systems. Since SMS is introduced by the Canadian Department of transportation, the Federal Aviation Administration (FAA) and the European Aviation Safety Agency (EASA) are also actively promoting the application of SMS in the field of aviation safety.

In Mar 2006, ICAO incorporated SMS in its International Civil Aviation Covenant and prescribed the requirements of aircraft operator, air traffic service organization and Airport to implement acceptable SMS system for Civil Aviation Management Department [4]. In 2007, ICAO revised its Annex 8 (Airworthiness of aircraft), and further extended the requirement of implementation SMS from aircraft operating organization to its design and manufacturing organization [5]. To resolve the contradiction between the rapid development of air transport market and safety operation, civil aviation in China also needs the methods of safety management system. As early as in 2005, SMS had been incorporated into the "civil aviation safety production in China's the eleventh Five -Year planning", Airlines, airports, air traffic control department and maintenance organization are currently required to make the project implementation plan and Roadmap to promote the construction of SMS [6]. Similarly, China's civil aviation is also in accordance with the requirements of ICAO to further promotion the implementation of SMS in aircraft design and manufacturing organization. However, the airworthiness management requirements and established requirements for airworthiness management system in current aircraft design and manufacturing organization are distributed in different procedures, there are still not have relevant regulations and implementation plan to implement the core idea of SMS, there is still a gap between the goal of current airworthiness management system and safety management system. 
Therefore, in order to be more scientifically implementation of the SMS program, the differential and compatibility analysis between the available aircraft airworthiness management system and implementing SMS target is needed.

In Conclusion, through comparing and analyzing the differences between the requirements of existing airworthiness management system and SMS, based on the scientific theoretical model for construction of civil aviation safety management system, a preliminary discussion on the implementation recommendations to carry out safety management system in civil aircraft type design and manufacturing organization is presented.

\section{THEORETICAL BASIS}

In SMS, security is defined as a state. Through risk identification and risk management, system controls the risk in aircraft design, manufacturing and operation processes, and makes the risk below an acceptable levels. In the process of constructing SMS, The accident causing model of Reason and risk assessment method is an important theoretical basis.

The Reason model can be summarized the cause of the accident as the "Swiss cheese" model (Figure 1). The model was proposed by Professor James Reason in University of Manchester, and was recommended by ICAO to become one of the theoretical models for the investigation and analysis of the aviation accident.

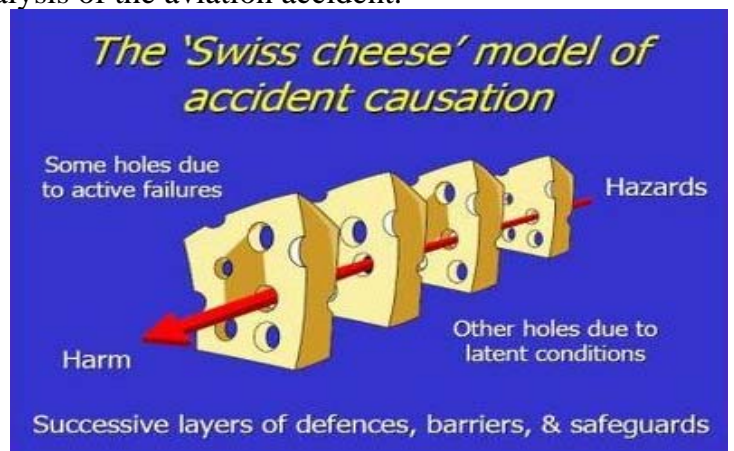

Figure 1. The accident causing model of Reason

The internal logic of the Reason model is based on that the accident can not only have the chain reaction of an event itself, also exists at the same time a penetration in the defected organization. Promoting factors for accident and organizational defect (or safety risk) at all levels have a long-standing state and are continuing to evolve by themselves, but these accidents and defect does not necessarily result in unsafe event. However, when multiple levels of organizational defects in a same accident factor occur at the same time or occur gradually in order, security event will lose its multi-level blocking barrier and an unsecured event will happened [7]. Reason stressed on the organization management factors in accident cause, and reduced the risk of accidents fundamentally. The continuing improve organization management system to an optimize level is the theoretical foundation of SMS.
The core of SMS is proactive risk management. An important part of the SMS is risk assessment. Considering the likelihood and severity of any adverse consequences could be occurred in the security system, and determine the acceptable level of risk. There are many methods of risk assessment, a simple method is introduced here to evaluate the risk of harm, namely, risk analysis matrix method [8,9]. Through collecting the event information, it is making the matrix form and makes relevant decisions, such as the risk of severe matrix (Figure 2) for example.

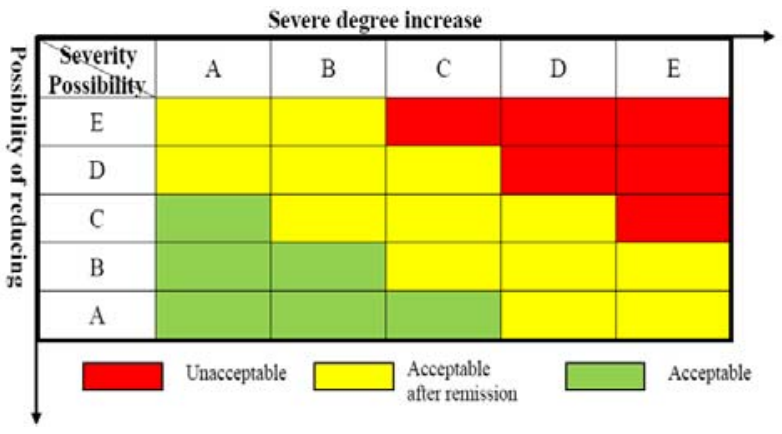

Figure 2. The risk of severe matrix

Among them, the green frame "acceptable" means there is no need to take further measures; Yellow frame "acceptable after remission” means the risk can be tolerated, but the precondition is that risk is decreasing as much as possible; Red Frame "unacceptable" means that the current state of working must be stopped until the risk has been decreased to a tolerable level at least.

\section{COMPARATIVE ANALYSIS}

The important content of assessment the construction and implementation of SMS in the aircraft design and manufacturing organization includes finding and recognizing downplayed or even ignored risk factors in the current aircraft airworthiness management, determining the acceptable level of risk, preventing these accidents and organization defects evolving to aviation accidents.

In order to coordinate the different airworthiness regulations on aircraft type design and manufacturing organization between FAA, EASA and CAAC, the forth revision of CCAR Part 21 'Certification Rules for Civil Aviation Products and Articles'(CCAR-21 R4) includes the requirements of Design Assurance System(DAS) for aircraft type design organization, and also proposed the requirement of Quality System(QS) for aircraft manufacture organization to corresponding with FAA and EASA regulation.

On the other hand, In order to guide and assistant to establish a SMS, the ICAO gives the SMS implementation analysis method and comparison analysis table in its "safety management manual" (Doc9859) [10], which embodies the ICAO's principle with SMS requirements.

Therefore, based on the current airworthiness management practice in aircraft design and manufacturing, the main research objective is to compare the requirement 
of CCAR-21 R4 and the requirement of SMS in Doc9859 on DAS and QS, and emphasize on the analysis of the similarities and differences between airworthiness management system and SMS in the design assurance, production certificate, quality control and surveillance.

\section{DIFFERENCE ANALYSIS}

Considering the pages limitation, the differences between airworthiness management system and SMS is listed here, as a valuable references for construction of a compatible airworthiness management with the requirements of the SMS system. Concerning of the core idea, Table I lists the difference of management objectives between current airworthiness management system and SMS. In contrast, the SMS will transfers a single event management and Subsequent investigation into the situation management, pays more attention to the overall risk control, emphasizes on accident prevention and safety planning, and undertakes risk information collection, analysis, monitoring and troubleshooting tasks.
TABLE I THE DIFFERENCE OF MANAGEMENT OBJECTIVES BETWEEN CURRENT AIRWORTHINESS MANAGEMENT SYSTEM AND SMS

\begin{tabular}{|l|l|l|l|l|}
\hline Category & Methods & Control & $\begin{array}{l}\text { Risk } \\
\text { Management }\end{array}$ & Result \\
\hline $\begin{array}{l}\text { Airworthiness } \\
\text { management } \\
\text { system }\end{array}$ & $\begin{array}{l}\text { Event } \\
\text { Management } \\
\text { Quality } \\
\text { Management }\end{array}$ & $\begin{array}{l}\text { Survey of } \\
\text { unsafe events } \\
\text { and } \\
\text { prevent the } \\
\text { similar } \\
\text { accident to } \\
\text { happen again }\end{array}$ & $\begin{array}{l}\text { Single } \\
\text { event } \\
\text { Protection }\end{array}$ & $\begin{array}{l}\text { Partial } \\
\text { safety }\end{array}$ \\
\hline & $\begin{array}{l}\text { Analysis of } \\
\text { hazard and } \\
\text { risk trend in } \\
\text { advance, } \\
\text { safety } \\
\text { warning, } \\
\text { prevent } \\
\text { unsafe } \\
\text { incidents }\end{array}$ & $\begin{array}{l}\text { The } \\
\text { overall } \\
\text { risk control }\end{array}$ & System \\
SMS & $\begin{array}{l}\text { Situation } \\
\text { Management } \\
\text { Managemantion }\end{array}$ & & \\
& Managent & & \\
\hline
\end{tabular}

From the specific implementation details, Table II focuses on the differences analysis between DAS, QS and SMS with respective to the following four sections, including the safety policy and objectives, security risk, security assurance, safety promotion, etc.

TABLE II. THE DIFFERENCES ANALYSIS BETWEEN DAS, QS AND SMS

\begin{tabular}{|c|c|c|}
\hline Doc 9859 & DAS & QS \\
\hline \multicolumn{3}{|l|}{ 1. The safety policy and objectives } \\
\hline $\begin{array}{l}\text { 1.1 Management commitment and } \\
\text { responsibility } \\
\text { In any organization, management } \\
\text { directly controls the use of staff activities } \\
\text { and/or necessary resources, which is } \\
\text { directly relevant to its provided service. } \\
\text { The main responsibilities of the safety } \\
\text { management are operating by integration } \\
\text { of the necessary risk control measures in } \\
\text { organization. SMS is the method of } \\
\text { management to carry out these } \\
\text { responsibilities. SMS is to ensure safe and } \\
\text { efficient operation of the management } \\
\text { system. }\end{array}$ & $\begin{array}{l}\text { In DAS, a security policy and the } \\
\text { necessary resources needed for the } \\
\text { implementation of security policies are } \\
\text { clearly presented, and DAS is able to carry } \\
\text { out self audit and monitor. } \\
\text { However, DAS lacks the specific } \\
\text { requirements for the operation of } \\
\text { unacceptable behavior, and is short of } \\
\text { exception condition for security information } \\
\text { report. There are no direct regulatory } \\
\text { requirements for associating security goal } \\
\text { with security performance indicators, safety } \\
\text { performance goals and action plans. }\end{array}$ & $\begin{array}{l}\text { In QS, a clear security policy is defined, which } \\
\text { covers the necessary resources required to } \\
\text { implement security policy. } \\
\text { However, similar with DAS, QS lacks the } \\
\text { specific requirements for the operation of } \\
\text { unacceptable behavior, and is short of exception } \\
\text { condition for security information report. } \\
\text { To eliminate the deviation of quality system, QS } \\
\text { requires corrective measures and preventive action. } \\
\text { At the same time, the civil aviation supervision } \\
\text { department also carries out surveillance. However, } \\
\text { There are no direct regulatory requirements for } \\
\text { associating security goal with security performance } \\
\text { indicators, safety performance goals and action } \\
\text { plans. }\end{array}$ \\
\hline $\begin{array}{l}\text { 1.2 Safety responsibility } \\
\text { The objective of ensuring the } \\
\text { responsibility of safe operation, and } \\
\text { achieving the balanced allocation of } \\
\text { resources, is accomplished through the } \\
\text { organization of the SMS itself, especially } \\
\text { to achieve through a special element of } \\
\text { SMS: determination for all staff safety } \\
\text { responsibility, and most important is to } \\
\text { determine the safety responsibility of the } \\
\text { core staff. }\end{array}$ & $\begin{array}{l}\text { DAS contains a list of work procedures, } \\
\text { but there is no requirement for personal } \\
\text { safety accountability requirements. } \\
\text { DAS does not require define the } \\
\text { implementation of safety responsibility of } \\
\text { the specific personnel, but requires the } \\
\text { system with independent monitoring } \\
\text { function; DAS also does not clearly defined } \\
\text { management level for security risk tolerance } \\
\text { decision. }\end{array}$ & $\begin{array}{l}\text { QS has no specific requirements of fiscal } \\
\text { resource control, human resource control on the } \\
\text { responsible person, } \\
\text { Similar with DAS, QS does not require define } \\
\text { the implementation of safety responsibility of the } \\
\text { specific personnel, but requires the system with } \\
\text { independent monitoring function; DAS also does } \\
\text { not clearly defined management level for security } \\
\text { risk tolerance decision. }\end{array}$ \\
\hline $\begin{array}{l}\text { 1.3 Core security personnel } \\
\text { appointment } \\
\text { The establishment of the effectively } \\
\text { office for security services, the key to } \\
\text { make it operate effectively is appointed } \\
\text { security service personnel, who is } \\
\text { responsible for the office daily operation. }\end{array}$ & $\begin{array}{l}\text { Almost identical with the requirement of } \\
\text { Doc } 9859\end{array}$ & $\begin{array}{l}\text { QS has no requirements to define and document } \\
\text { the security powers, duties and responsibilities for } \\
\text { all levels of staff. }\end{array}$ \\
\hline
\end{tabular}




\subsection{Emergency response plan}

After the accident, Emergency response plan (ERP) should write the rules of how to deal with the accident, and who is responsible for each step. The purpose of ERP is to ensure the orderly and effective conversion between the normal operation and emergency operations, including rights assignment and allocation of responsibilities in emergence.

\subsection{SMS document}

A significant feature of SMS is that all activities related to safety should be recorded, and these records are visible. That is to say, the document is one of the most important elements of SMS.
DAS establish a system to, collect, report, investigation and analysis of the fault, failure and defect in civil aviation products or components.

However, After the accident, DAS has no specific requirements of ERP on the emergence; There is no emergency response / emergencies plans and coordination plan in DAS.

DAS establishes a system to, collect, report, investigation and analysis of the fault, failure and defect in civil aviation products or components.

However, DAS does not have specific requirement for recording system a (identification, storage, protection, archiving, retrieval); there is no clear archive file management requirements of the risk event.
Similar with DAS, QS establish a system to, collect, report, investigation and analysis of the fault, failure and defect in civil aviation products or components.

However, After the accident, QS has no specific requirements of ERP on the emergence; There is no emergency response / emergencies plans and coordination plan in QS.

QS establishes a system to, collect, report, investigation and analysis of the fault, failure and defect in civil aviation products or components.

However, QS has no clear archive file management requirements of the risk event.

TABLE III. THE DIFFERENCES ANALYSIS BETWEEN DAS, QS AND SMS(CONTINUE)

\begin{tabular}{|c|c|c|}
\hline Doc 9859 & DAS & QS \\
\hline \multicolumn{3}{|c|}{ 2. Security risk } \\
\hline $\begin{array}{l}\text { 2.1 Risk source identification } \\
\text { The organization shall establish and } \\
\text { maintain formal procedures to ensure that the } \\
\text { source of danger in the operation identified. } \\
\text { Risk source identification must be based on the } \\
\text { safety data collection from multiple ways of } \\
\text { passive, active and prediction method. }\end{array}$ & $\begin{array}{l}\text { DAS did not require develop active / } \\
\text { prediction methods for safety data collection. } \\
\text { Management has not mandatory to audit the } \\
\text { passive report. } \\
\text { No data forecasting, early warning and risk } \\
\text { communication mechanism requirement in } \\
\text { DAS }\end{array}$ & $\begin{array}{l}\text { QS did not require develop active / } \\
\text { prediction methods for safety data collection. } \\
\text { Management has not mandatory to audit the } \\
\text { passive report. } \\
\text { No data forecasting, early warning and } \\
\text { risk communication mechanism requirement } \\
\text { in QS }\end{array}$ \\
\hline $\begin{array}{l}\text { 2.2 Security risk assessment and mitigation } \\
\text { The organization shall establish and } \\
\text { maintain a formal procedure to ensure the } \\
\text { analysis, evaluation and control of safety risk } \\
\text { in organization operation. }\end{array}$ & $\begin{array}{l}\text { The DAS does not require a clear } \\
\text { expression of dangerous source, the } \\
\text { relationship between risk and safety } \\
\text { consequences. }\end{array}$ & $\begin{array}{l}\text { The QS does not require a clear } \\
\text { expression of dangerous source, the } \\
\text { relationship between risk and safety } \\
\text { consequences. }\end{array}$ \\
\hline
\end{tabular}

TABLE IV. THE DIFFERENCES ANALYSIS BETWEEN DAS, QS AND SMS(CONTINUE)

\begin{tabular}{|c|c|c|}
\hline Doc 9859 & DAS & QS \\
\hline \multicolumn{3}{|l|}{ 3. Security assurance } \\
\hline $\begin{array}{l}\text { 1.1 Safety performance monitoring and evaluation } \\
\text { Organization must develop and maintain the methods to } \\
\text { monitor organization safety performance, to confirm the } \\
\text { validity of the security risk control. The safety performance } \\
\text { of the organization must refer to the safety of SMS } \\
\text { performance index and safety performance targets. }\end{array}$ & $\begin{array}{l}\text { In DAS, management has not } \\
\text { mandatory to audit the safety } \\
\text { report. } \\
\text { DAS has no requirements for } \\
\text { monitoring and analysis of the } \\
\text { trend of risk. }\end{array}$ & $\begin{array}{l}\text { In QS, management has not mandatory to } \\
\text { audit the safety report. } \\
\text { QS has no requirements for monitoring } \\
\text { and analysis of the trend of risk. } \\
\text { QS has no selection / training procedure } \\
\text { to ensure objectivity and ability of auditors. }\end{array}$ \\
\hline $\begin{array}{l}\text { 1.2 Management change } \\
\text { The organization must develop and maintain a formal } \\
\text { procedures to identify possible effects of organization } \\
\text { change on existing programs and services; } \\
\text { The organization should describe the arrangement } \\
\text { before implementation of these change in order to ensure the } \\
\text { safety performance; } \\
\text { The organization should cancel or modify those no } \\
\text { longer need or no longer valid safety risk control due to } \\
\text { operating environment changed. }\end{array}$ & $\begin{array}{l}\text { For staff positions change and } \\
\text { responsibility change, DAS has } \\
\text { no active risk assessment and risk } \\
\text { management requirements for } \\
\text { these change, DAS also did not } \\
\text { take the initiative to adjust the } \\
\text { working procedure rules and } \\
\text { requirements. }\end{array}$ & $\begin{array}{l}\text { For staff positions change and } \\
\text { responsibility change, QS has no active risk } \\
\text { assessment and risk management } \\
\text { requirements for these change, QS also did } \\
\text { not take the initiative to adjust the working } \\
\text { procedure rules and requirements. }\end{array}$ \\
\hline $\begin{array}{l}\text { 1.3 SMS continuing Improvement } \\
\text { The organization must develop and maintain a formal } \\
\text { procedure to determine the causes of performance in SMS } \\
\text { lower than normal target. } \\
\text { The organization should determine the impact of this } \\
\text { below standard performance in operation, and eliminate or } \\
\text { mitigate these reasons. }\end{array}$ & $\begin{array}{l}\text { Almost identical with the } \\
\text { requirement of Doc } 9859\end{array}$ & $\begin{array}{l}\text { Almost identical with the requirement of } \\
\text { Doc } 9859\end{array}$ \\
\hline
\end{tabular}


TABLE V. THE DIFFERENCES ANALYSIS BETWEEN DAS, QS AND SMS(CONTINUE)

\begin{tabular}{|c|c|c|}
\hline Doc 9859 & DAS & QS \\
\hline \multicolumn{3}{|l|}{ 4. Safety promotion } \\
\hline $\begin{array}{l}\text { 4.1 Training and education } \\
\text { The organization shall establish and maintain a safety } \\
\text { training program to ensure that all employees are trained } \\
\text { and competent for SMS task. Range of safety training } \\
\text { should be appropriate for everyone to participate in the } \\
\text { degree of SMS }\end{array}$ & $\begin{array}{l}\text { The DAS has no clear training } \\
\text { requirements. }\end{array}$ & The QS has no clear training requirements. \\
\hline $\begin{array}{l}\text { 4.2 Safety communication } \\
\text { The organization should develop and maintain an } \\
\text { official method of safety communication to ensure that all } \\
\text { employees can understand SMS, convey important } \\
\text { information related to security, explain the reasons to take } \\
\text { special safety operations, and the reason to introduce or } \\
\text { change safety procedures. }\end{array}$ & $\begin{array}{l}\text { DAS did not explain the specific } \\
\text { provisions of the system change or } \\
\text { the introduction of safety } \\
\text { procedures }\end{array}$ & $\begin{array}{l}\text { QS did not explain the specific provisions of } \\
\text { the system change or the introduction of } \\
\text { safety procedures }\end{array}$ \\
\hline
\end{tabular}

In conclusion, the current airworthiness management system (DAS and QS) established in civil aircraft design and manufacturing organization is intrinsically linked to the SMS, mainly in the following three aspects;

i. DAS in aircraft type design organization and QS in aircraft manufacturing organizations clearly covered airworthiness (safety) responsibility. The design / manufacturing work, the relevant responsibilities and products airworthiness is carried through the implementation of design assurance manual and quality assurance manual;

ii. DAS and QS require the organization to collect, report, analysis of security problem related to products and safety problems due to deviation, and make relevant corrective actions;

iii. DAS and QS have independent monitoring and internal audit functions, which is used to find and correct the problems existing in operation.

However, for final transition of DAS and QS to meet the requirements of SMS, the current DAS and QS have at least the following underestimated or even overlooked factors.

i. Overlooked factors

1). Risk trends analysis and safety early warning function. Identify and solve the potential security risk.

2 ). The exemption requirements for staff report on potential errors. Encourage staff to report on trends in the risk and potential errors, increase the data source of risk trend analysis, and improve safety early warning ability.

ii. Underestimated factors

1). Responsibilities, rights and accountability requirements for the specific management personnel, quality manager and the working layer; Establish Emergency response plan (ERP).

2). Personnel selection procedures, personnel qualification and training requirement.

3). Safety management activities recording and archiving.

4). Specific measures for the necessary resources into operation of the quality system.

\section{V.SUMMARY}

By contrast, there is no essential different between the current airworthiness management system and SMS. It is feasible for aircraft type design and manufacturing organization with established current DAS and QS to establish SMS.

According to the differences analysis, in addition to the direct establishment of SMS, another feasible way is introduce SMS requirements in the aircraft airworthiness management regulations, and gradually transit to SMS. Through incorporating security elements of SMS, this scheme will not escape from the established quality management system and more emphasis on information decision, operation data collection and integration, improve the audit system, feedback the investigation of accidents, but also overcome the shortcoming of quality management.

\section{ACKNOWLEDGMENT}

The national soft science research program (2010GXQ5B302).

\section{CORRESPONDING AUTHOR}

Name: Sheng LI, Email: lish@mail.castc.org.cn, Tell: +861064481172.

\section{REFERENCES}

[1] China Civil Aviation Regulations Part 21(CAAC Publications, China 2007).

[2] SUN Yijie, ZHANG Yuan, LI Jing. Study on programme of risk management in aircraft design and manufacture organization. Journal of Safety Science and Technology, 2012, 12(8):132-137.

[3] ICAO Annex 8 'Airworthiness of Aircraft' (ICAO Publications, Canada 2005) .

[4] Gao Zhu, Xu Baoguang. interpretation on the Aviation Safety Management System . Science \& Technology For Development, 2012(3): 11-15.

[5] YU liling. Synergetic SMS Structure of China Civil Aviation. Journal of Civil Aviation University of China, 2008, 26(6):48-55.

[6] ZHAO Peng, Song Cunyi. Consideration of SMS of civil aviation in China. Journal of Safety Science and Technology, 2007,3(1):99-101. 
[7] CHEN Nongtian, TAN Xin, LI Rui. Application of REASON Model to Investigation of the Aviation Maintenance Accident, Computer and Communications, 2012,2 (4): 96-98

[8] WEI Yi, CHEN Xin-feng, Research of Safety Risk Evaluation for Service Difficulty Report, Journal of Civil Aviation University of China , 2011, 2 (5):42-46.
[9] QIAO Lei, The research of establish a new SMS in Dalian Aircraft Maintenance Factory [Thesis], 2006

[10] ICAO Safety Management Manual, Doc.9859.AN/474. (ICAO Publications, Canada 2009) 